\title{
ANTESEDEN PEMBENTUK KEPUASAN KONSUMEN (STUDI PADA KONSUMEN TAS RUMAH WARNA YOGYAKARTA)
}

\author{
Khalifah Nurjannah \\ khalifahnurjannah209@yahoo.co.id \\ Universitas Ahmad Dahlan \\ Fitroh Adhilla \\ fitauad@yahoo.com \\ Universitas Ahmad Dahlan
}

\begin{abstract}
ABSTRAK
This study aims to determine the effect of the three forming factors consumer satisfaction consisting of product quality, brand image and price affect consumer satisfaction Rumah Yogyakarta bag colors both partial or simultaneous. This research is a quantitative research. Sampling with non probability sampling with purposive sampling technique that has criteria is a consumer of the Yogyakarta Color House bag female, have bought and used a Rumah Warna bag, and are $>18$ years old year. Data collection in this study uses deployment questionnaire to be tested for validity and reliability, for data analysis using multiple regression analysis, $t$ test, $\mathrm{f}$ test and $\mathrm{R}$ square. Subject this research is the consumers of Rumah Warna Yogyakarta bag already once bought and used a Rumah Color bag. The results showed that: 1) the quality of the product on the bag Rumah Warna does not have a significant effect on bag customer satisfaction Rumah Warna Yogyakarta, 2) brand image on Rumah Warna bag is influentialsignificant positive effect on customer satisfaction Rumah Warna Yogyakarta bag, 3) the price on the Rumah Warna bag has a significant positive effect on satisfaction Yogyakarta Rumah Color bag consumers, and 4) together quality product, brand image and price have a significant positive effect on satisfaction Yogyakarta Rumah Color bag consumers with an $\mathrm{f}$ test result of $0,000<0.05$, with a regression equation $\mathrm{Y}=$ $0.237+0.218 \mathrm{X} 1+0.337 \mathrm{X} 2+0.396 \mathrm{X} 3+\mathrm{e}$. R Square of 0.496 or $49.6 \%$ which influences and the remaining $50.4 \%$ influenced by other variables not examined by this study.
\end{abstract}

Keywords: customer relation with the company Rumah Warna's bag, product quality, brand image, price and customer satisfaction..

\section{PENDAHULUAN}

Perkembangan dunia fashion di Indonesia sangatlah pesat, hal ini terlihat dari beragamnya produk-produk fashion yang mulai menjamur di pasaran dengan berbagai macam gaya fashion. Fashion merupakan hal yang melekat disetiap individu kapanpun dan dimanapun, fashion adalah hal yang tidak pernah luput dari perhatian. Kebutuhan gaya hidup masyarakat mengenai fashion tidak hanya tentang pakaian, masyarakat membutuhkan tas untuk menunjang penampilan lebih modis.

Di era perdagangan bebas sekarang ini banyak sekali perusahaan asing yang mulai menguasai trend fashion masyarakat lokal. Bahkan masyarakat lebih memilih mengoleksi tas-tas impor untuk menunjang penampilan mereka. Dengan begitu merek lokal tentunya akan kalah bersaing dengan merek luar negeri yang mulai merambah pasar lokal. Merek tas luar negeri tersebut memasuki pasar lokal dengan berbagai macam cara tidak hanya dengan 
membuka toko langsung di Indonesia, tetapi juga dengan perdagangan secara online, sehingga masyarakat lokal tidak perlu bersusah payah jauh-jauh keluar negeri untuk menambah koleksi tas produksi luar negeri milik mereka. Hal ini tentunya menjadi ancaman bagi produsen lokal seperti merek lokal tas Rumah Warna.

Rumah Warna dikenal sebagai merek pernak-pernik remaja putri dengan tas sebagai produk utamanya. Berawal dari industri rumahan produk-produk Rumah Warna merupakan karya asli yang dihasilkan dari pemikiran kreatif pemilik bersama timnya. Setiap bulan, produk dengan desain terbaru selalu di produksi dengan melewati survey pasar dan quality control. Jadi, produk rumah warna selalu mengikuti perkembangan zaman. Hingga saat ini Rumah Warna memiliki lebih dari 300 desain tas dan dompet. Nama Rumah Warna juga digunakan sebagai merek pada produk yang dihasilkan.

Produk yang dihasilkan Rumah Warna adalah produk lokal yang diproduksi mengikuti perkembangan zaman. Di Indonesia, khususnya di Yogyakarta merek Rumah Warna sudah cukup terkenal baik dari segi kualitas produknya yang memang diproduksi dengan baik dan sesuai SOP Rumah Warna, model tas yang tidak pernah ketinggalan zaman karena selalu mengikuti tren yang sedang berkembang dan juga dari keunikan warna yang dimiliki oleh tas Rumah Warna dengan cara memadupandankan warna-warna yang tidak biasa tetapi ternyata hasilnya justru sangat unik dan fashionable. Desain tas merek Rumah Warna beraneka ragam, mulai dari tas punggung atau ransel, tas tangan dan tas slempang. Harga yang ditawarkan tas Rumah Warna juga sangat bervariasi sehingga konsumen dapat memilih produk yang konsumen inginkan yang sesuai dengan kantong konsumen yang umumnya adalah remaja, dan juga dewasa. Tas Rumah Warna memang didesain untuk kalangan remaja, tetapi bukan tidak mungkin bahwa pelanggan pengguna tas Rumah Warna datang dari kalangan ibu-ibu yang sudah berkeluarga dan tergolong sudah tidak muda lagi.

Selain menawarkan desain dan warna yang menarik, Rumah Warna juga memberikan fasilitas pelayanan berupa garansi kerusakan kepada konsumen tas Rumah Warna. Garansi yang diberikan Rumah Warna adalah garansi seumur hidup, sehingga jika kita membeli tas di Rumah Warna dan saat kita pakai mengalami kerusakan, kita dapat dengan mudah dan tanpa mengeluarkan biaya kembali untuk memperbaiaki tas tersebut.

Kualitas suatu produk sangatlah penting bagi setiap pendiri perusahaan, terlebih lagi produk tas adalah barang yang sangat dibutuhkan oleh wanita yang pada dasarnya wanita cenderung memperhatikan kualitas barang yang akan ia gunakan. Saputri (2017) menyatakan bahwa, kualitas produk adalah sejauh mana suatu produk yang diberikan perusahaan mampu memenuhi kebutuhan dan harapan konsumen.

Sari dan Yuniati (2016) citra merek adalah persepsi dan kepercayaan konsumen terhadap merek barang atau jasa yang memperluas loyalitas merek dan meningkatkan pembelian ulang. Perusahaan berusaha untuk menciptakan suatu citra yang baik, tepat dan sesuai dengan selera konsumen terhadap produk dan jasa yang dihasilkan. Citra adalah suatu gambaran, penyerupaan kesan atau garis besar, bahkan bayangan yang dimiliki oleh seseorang terhadap sesuatu, oleh karena itu citra dapat dipertahankan.

Saputri (2017) menyatakan bahwa harga adalah pernyataan nilai dari suatu produk, dimana nilai meliputi perbandingan antara persepsi terhadap manfaat dengan biaya yang dikeluarkan untuk mendapatkan suatu produk. Saputri (2017) menyatakan bahwa kepuasan (satisfaction) adalah perasaan senang atau kecewa seseorang yang timbul karena membandingkan kinerja yang 
dipersepsikan produk (hasil) terhadap ekspetasi mereka.

Tujuan dari penelitian ini di antaranya: 1) untuk menganalisis pengaruh positif kualitas produk terhadap kepuasan pada konsumen tas Rumah Warna Yogyakarta, 2) untuk menganalisis pengaruh positif citra merek terhadap kepuasan pada kosumen tas Rumah Warna Yogyakarta, 3) untuk menganalisis pengaruh positif harga terhadap kepuasan pada kosumen tas Rumah Warna Yogyakarta dan 4) untuk menganalisis pengaruh kualitas produk, citra merek dan harga secara bersama-sama terhadap kepuasan pada konsumen tas Rumah Warna Yogyakarta.

\section{REVIEW LITERATUR DAN HIPOTESIS}

\section{Landasan Teori}

\section{Kualitas Produk}

Menurut Supangkat (2017) kualitas produk adalah karakteristik produk atau jasa yang bergantung pada kemampuannya untuk memuaskan kebutuhan pelanggan dinyatakan atau diimplikasikan. Pandangan konsumen akan kualitas sangat berbeda dengan kualitas menurut pandangan perusahaan.

\section{Citra Merek}

Menurut Rahmasari (2015) citra merek adalah Segala hal yang terkait dengan merek yang ada di benak ingatan konsumen. Citra merek yang merupakan persepsi konsumen terhadap merek secara menyeluruh dan dibentuk. Citra merek mempunyai peran penting dalam mempengaruhi perilaku pembelian. Konsumen yang mempunyai citra positif terhadap merek cenderung memilih merek tersebut dalam pembelian.
3. Harga

Tjiptono (2012) menyatakan bahwa harga merupakan salah satu elemen bauran pemasaran yang membutuhkan pertimbangan cermat.

4. Kepuasan Konsumen

Tjiptono (2012) menyatakan bahwa kepuasan atau ketidak puasan pelanggan sangat krusial bagi kalangan bisnis, pemerintah dan juga konsumen. Bagi bisnis, kepuasan dipandang sebagai salah satu dimensi kinerja pasar. Peningkatan kepuasan pelanggan berpotensi mengarah pada pertumbuhan penjualan jangka panjang dan jangka pendek, serta pangsa pasar sebagai hasil pembelian ulang. Sementara itu, ketidakpuasan pelanggan memunculkan sejumlah risiko, seperti baikot atau protes dari lembaga konsumen, komplain pelanggan, intervensi pemerintah, reaksi pesaing dan masuknya produk substitusi baru ke pasar. Ketidakpuasan pelanggan sesungguhnya bisa membantu perusahaan mengidentifikasi aspek-aspek yang menjadi kelemahan produk atau jasanya yang tidak mampu memenuhi standar konsumen dan pemerintah.

\section{Hipotesis}

H1: Terdapat pengaruh positif kualitas produk terhadap kepuasan pada konsumen tas Rumah Warna Yogyakarta.

$\mathrm{H} 2$ : Terdapat pengaruh positif citra merek terhadap kepuasan pada konsumen tas Rumah Warna Yogyakarta.

H3: Terdapat pengaruh positif harga terhadap kepuasan pada konsumen tas Rumah Warna Yogyakarta. 
H4: Terdapat pengaruh kualitas produk, citra merek dan harga secara bersama-sama terhadap kepuasan pada konsumen tas Rumah Warna Yogyakarta.

\section{METODE PENELITIAN}

\section{Populasi dan Sampel}

Menurut Sugiyono (2017), populasi adalah wilayah generalisasi yang terdiri atas obyek/subyek yang mempunyai kualitas dan karakteristik tertentu yang ditetapkan oleh peneliti untuk dipelajari dan kemudian ditarik kesimpulannya. Populasi dalam penelitian ini adalah konsumen tas Rumah WarnaYogyakarta. Metode yang digunakan dalam penyampelan di penelitian ini menggunakan non probability sampling dengan teknik purposive sampling yaitu teknik penentuan sampel dengan pertimbangan tertentu. Penelitian ini menggunakan metode purposive sampling karena responden yang dituju adalah responden berjenis kelamin wanita yang sudah pernah membeli dan menggunakan tas Rumah Warna Yogyakarta minimal 2 kali transaksi pembelian dan berusia minimal 18 tahun.

Sugiyono (2017) menambahkan bila dalam penelitian akan melakukan analisis dengan multivariate (korelasi atau regresi ganda misalnya), maka jumlah anggota sampel minimal 10 kali dari jumlah variabel yang diteliti. Jumlah variabel dalam penelitian ini adalah 4 (independen +1 dependen) variabel. Jadi dapat ditentukan bahwa jumlah sampel yang dapat digunakan yaitu minimal 40 (empat puluh) sampel, sehingga target sampel adalah sebanyak 50 (lima puluh) sampel.

\section{Definisi Operasional}

1. Variabel Independen

a. Kualitas Produk (X1)

Kunaifi (2015) suatu barang dapat dinilai bagus atau tidaknya dari seluruh kemampuan yang dapat dilakukan oleh suatu produk, semakin produk mampu memberikan kinerja yang sesuai dengan ekspektasi penggunanya disitulah barang dinilai bagus maupun memuaskan. Kunaifi (2015) menambahkan menyatakan bahwa kualitas produk didefinisikan sebagai evaluasi menyeluruh pelanggan atas kebaikan kinerja barang atau jasa.

b. Citra Merek (X2)

Supangkat (2017) menyatakan bahwa, konsumen dengan citra yang positif terhadap suatu merek, maka lebih memungkinkan untuk melakukan pembelian. Setiap perusahaan pasti berusaha untuk membuat citra merek yang baik dimata konsumen dan berusaha untuk memenuhi selera konsumen akan produk yang dihasilkan. Selain citra merek, kualitas dari produk juga sangat penting bagi konsumen.

c. Harga (X3)

Rochman (2013) menyatakan bahwa harga adalah sejumlah uang yang dibayarkan untuk memperoleh produk yang diinginkan. Dalam pengertian yang lebih luas, harga adalah sejumlah pengorbanan yang diperlukan untuk mendapatkan suatu produk.

\section{Variabel Dependen}

Rahmasari (2015) menyatakan bahwa dengan mengetahui tingkat kepuasan konsumen, perusahaan dapat melakukan antisipasi terhadap kriteria dari suatu produk. Berawal dari pengalaman, cerita atau informasi dari 
teman atau relasi atau pihak-pihak lain dan janji yang diberikan oleh marketer terhadap suatu produk, akan membentuk suatu harapan bagi konsumen. Harapan dari konsumen dibandingkan dengan kinerja suatu produk akan membentuk dua kondisi, yaitu kepuasan konsumen atau ketidakpuasan konsumen.

\section{Uji Instrumen}

1. Uji Validitas

Sugiyono (2017) menyatakan bahwa, instrumen yang valid berarti alat ukur yang digunakan untuk mendapatkan data (mengukur) itu valid. Valid berarti instrumen tersebut dapat digunakan untuk mengukur apa yang seharusnya diukur.

Adhila (2014) menyatakan bahwa suatu kuisioner dikatakan valid jika pertanyaan pada kuisioner mampu untuk mengungkapkan sesuatu yang akan diukur apakah pertanyaan dalam kuisioner yang sudah kita buat betul-betul dapat mengukur apa yang hendak kita ukur. Pengujian validitas umumnya dilakukan dengan menyebarkan kuisioner untuk sampel kecil yaitu sebanyak 30 responden.

Uji Instrumen dicobakan pada sampel dari mana populasi diambil. (pengujian pengalaman empiris ditunjukkan pada pengajuan validitas external) Jumlah anggota sampel yang digunakan sekitar 30 orang. Setelah data ditabulasikan, maka pengujian validitas konstruksi dilakukan dengan analisis faktor (Confirmatory Factor Analysis). Indikator variabel dikatakan valid apabila nilai factor loading lebih besar dari 0,5 dan membentuk satu komponen.

2. Uji Reliabilitas

Adhila (2014) menyatakan bahwa reliabilitas adalah alat untuk mengukur suatu kuisioner yang merupakan indikator dari variabel atau konstruk. Suatu kuisioner dikatakan reliabel atau handal jika jawaban seseorang terhadap pernyataan adalah konsisten atau stabil dari waktu ke waktu. Adhila (2014) menambahkan bahwa pengukuran reliabilitas pada penelitian ini menggunakan metode one shoot atau pengukuran sekali saja. One shoot atau pengukuran sekali saja, disini pengukurannya hanya sekali kemudian hasilnya dibandingkan dengan pertanyaan lain atau mengukur korelasi antar jawaban pertanyaan. SPSS memberikan fasilitas untuk mengukur reliabilitas dengan uji statistic Cronbach Alpha ( $\alpha)$. Suatu konstruk atau variabel dikatakan reliabel jika memberikan nilai Cronbach Alpha >0.60.

\section{Teknik Analisis Data}

1. Analisis Regresi Berganda

Analisis yang digunakan adalah analisis regresi berganda, analisis ini digunakan untuk mengetahui analisis kualitas produk, citra merek dan harga terhadap kepuasan konsumen pengguna tas Rumah Warna Yogyakarta. Teknik regresi digunakan untuk melakukan prediksi seberapa jauh nilai variabel independen (X) mempengaruhi variabel dependen (Y). Persamaan regresi berganda:

$Y=a+\beta 1 X 1+\beta 2 X 2+\beta 3 X 3$

Keterangan:

Y : Kepuasan konsumen

a : Nilai konsumen

$\beta 1, \beta 2, \beta 3$ : Koefisisen regresi variabel independent

$\mathrm{X} 1$ : Kualitas produk

$\mathrm{X} 2$ : Citra merek

X3 : Harga 
2. Uji Parsial (Uji T)

Uji ini dilakukan untuk mengetahui variabel independen yaitu kualitas produk, citra merek dan harga terhadap kepuasan konsumen. Untuk melakukan uji $\mathrm{T}$ bisalangsung menggunakan analisis data dengan SPSS (statisrical product and service solution), dengan harapan mendapatkan hasil yang akurat. Hasil pengujian SPSS tersebut akan dilihat dengan cara membandingkan nilai sig hitung dengan $\alpha 0.05$ yang mempunyai kriteria pengujian sebagai berikut:

Jika sig hitung $>\alpha 0.05$ maka Ho diterima sedangkan Ha ditolak.

Jika sig hitung $<\alpha 0.05$ maka Ho ditolak sedangkan Ha diterima.

\section{Uji Simultan (Uji F)}

Uji hipotesis dengan F-test digunakan untuk menguji hubungan variabel bebas secara bersama-sama mempengaruhi variabel terikat. Uji yang akan dilakukan adalah untuk mengetahui apakah variabel kualitas produk, citra merek dan harga berpengaruh secara bersama-sama terhadap kepuasan konsumen. Untuk melakukan uji $F$ bisa langsung menggunakan analisis data dengan SPSS (statisrical product and service solution), dengan harapan mendapatkan hasil yang akurat. Hasil pengujian SPSS tersebut akan dilihat dengan cara membandingkan nilai sig hitung degan $\alpha 0.05$ yang mempunyai kriteria pengujian sebagai berikut:

Jika sig hitung $>\alpha 0.05$ maka Ho diterima sedangka Ha ditolak.

Jika sig hitung $<\alpha \quad 0.05$ maka Ho ditolak sedangkan Ha diterima.

\section{Uji Koefisien Determinasi}

Melihat nilai $\mathrm{R}$ square untuk mengetahui seberapa besar keterkaitan dari variabel independen yaitu kualitas produk, citra merek dan harga terhadap variabel dependen kepuasan konsumen tas Rumah Warna Yogyakarta.

Firrahim (2018) mengatakan bahwa, koefisien determinasi (R2) pada intinya mengukur seberapa jauh kemampuan model dalam menerangkan variasi variabel dependen. Nilai koefisien determinasi adalah adalah antara nol dan satu. Nilai R2 yang kecil berarti kemampuan variabel-variabel independen dalam menjelaskan variabel-variabel dependen amat terbatas. Nilai yang mendekati satu berarti variabel-variabel independen memberikan hampir semua informasi yang dibutuhkan untuk memprediksi variasi-variasi dependen.

\section{HASIL PENELITIAN DAN PEMBAHASAN}

\section{Hasil Analisis Responden}

1. Responden Menurut Jenis Kelamin

\begin{tabular}{|r|c|c|c|}
\hline Jo. & Jenis Kelamin & $\begin{array}{c}\text { Jumlah } \\
\text { (Responden) }\end{array}$ & $\begin{array}{c}\text { Frekuensi } \\
(\%)\end{array}$ \\
\hline 1. & Perempuan & 50 & $100 \%$ \\
\hline 2. & Laki-laki & 0 & $0 \%$ \\
\hline
\end{tabular}

Berdasarkan kuisioner yang dibagikan kepada responden dapat diketahui bahwa jumlah sampel seluruhnya berjenis kelamin perempuan (100\%), sesuai dengan target sampel yang sudah ditentukan bahwa data penelitian ini hanya berlaku untuk konsumen tas rumah warna yang berjenis kelamin perempuan.

2. Responden Menurut Usia

\begin{tabular}{|c|c|c|c|}
\hline No. & Usia & $\begin{array}{c}\text { Jumlah } \\
\text { (responden) }\end{array}$ & $\begin{array}{c}\text { Frekuensi } \\
(\%)\end{array}$ \\
\hline 1 & 18-25 Tahun & 40 & $80 \%$ \\
\hline 2 & 26-35 Tahun & 8 & $16 \%$ \\
\hline 3 & $36-45$ Tahun & 2 & $4 \%$ \\
\hline 4 & $>45$ Tahun & - & $0 \%$ \\
\hline
\end{tabular}

Berdasarkan tabel di atas responden dengan usia antara 18-25 tahun adalah responden terbanyak dengan jumlah 40 responden $(80 \%)$ selanjutnya usia antara 26-35 tahun 
berjumlah 8 responden $(16 \%)$, responden yang berusia antara $36-45$ tahun dengan jumlah 2 responden $(4 \%)$ dan usia $>45$ tahun dengan jumlah 0 responden $(0 \%)$.

3. Responden Menurut Status Hubungan

\begin{tabular}{|c|c|c|c|}
\hline No. & $\begin{array}{c}\text { Status } \\
\text { Hubungan }\end{array}$ & $\begin{array}{c}\text { Jumlah } \\
\text { (responden) }\end{array}$ & $\begin{array}{c}\text { Frekuensi } \\
(\%)\end{array}$ \\
\hline 1 & Menikah & 9 & $18 \%$ \\
\hline 2 & Belum Menikah & 41 & $82 \%$ \\
\hline
\end{tabular}

Berdasarkan data yang diperoleh responden dengan status hubungan yang telah menikah berjumlah 9 responden $(18 \%)$ dan belum menikah berjumlah 41 responden $(82 \%)$.

4. Responden Menurut Kualifikasi Pendidikan

Jumlah Responden Menurut Kualifikasi Pendidikan
\begin{tabular}{|c|c|c|c|}
\hline No. & $\begin{array}{c}\text { Kualifikasi } \\
\text { Pendidikan }\end{array}$ & Jumlah & $\begin{array}{c}\text { Frekuensi } \\
(\%)\end{array}$ \\
\hline 1 & SD & 0 & $0 \%$ \\
\hline 2 & SMP & 0 & $0 \%$ \\
\hline 3 & SMA & 24 & $48 \%$ \\
\hline 4 & Sarjana & 22 & $44 \%$ \\
\hline 5 & Lainya & 4 & $8 \%$ \\
\hline
\end{tabular}

Berdasarkan data yang diperoleh jumlah responden menurut kualifikasi pendidikan dari yang terendah yaitu tingkat SD (Sekolah Dasar) berjumlah 0 responden (0\%), selanjutnya SMP (Sekolah Menengah Pertama) 0 responden (0\%), SMA (Sekolah Menengah Atas) berjumlah 24 responden (48\%), Sarjana berjumlah 22 responden (44\%) dan kualifikasi pendidikan lainnya berjumlah 4 responden $(8 \%)$.

5. Responden Menurut Status Pekerjaan

\begin{tabular}{|c|c|c|c|}
\hline No. & Status Pekerjaan & Jumlah & $\begin{array}{c}\text { Frekuensi } \\
(\%)\end{array}$ \\
\hline 1 & Pelajar/Mahasiswa & 35 & $70 \%$ \\
\hline 2 & Wiraswasta & 8 & $16 \%$ \\
\hline 3 & PNS & 6 & $12 \%$ \\
\hline 4 & Ibu Rumah Tangga & 1 & $2 \%$ \\
\hline
\end{tabular}

Bedasarkan data yang diperoleh jumlah responden menurut status pekerjaan pelajar/mahasiswa berjumlah paling banyak dibandingkan dengan jumlah yang lain yaitu berjumlah 35 responden $(70 \%)$, sedangkah jumlah terbanyak selanjutnya yaitu status pekerjaan wiraswasta berjumlah 8 responden (16\%), status pekerjaan PNS (Pegawai Negeri Sipil) berjumlah 6responden (12\%), dan Ibu rumah tangga berjumlah 1 responden $(2 \%)$.

6. Responden Menurut Waktu Penggunaan Tas Rumah Warna Jumlah Responden Menurut Waktu Penggunaan Tas Rumah

\begin{tabular}{|r|c|c|c|}
\hline No. & $\begin{array}{c}\text { Warna } \\
\text { Penggunaan Kartu } \\
\text { Keanggotaan }\end{array}$ & Jumlah & $\begin{array}{c}\text { Frekuensi } \\
(\%)\end{array}$ \\
\hline 1. & $0-6$ Bulan & 19 & $38 \%$ \\
\hline 2. & $7-11$ Bulan & 5 & $10 \%$ \\
\hline 3. & 1-3 Tahun & 19 & $38 \%$ \\
\hline 4. & $>3$ Tahun & 7 & $14 \%$ \\
\hline
\end{tabular}

Berdasarkan data yang diperoleh jumlah responden menurut waktu pengguaan tas Rumah Warna 0-6 bulan berjumlah 19 responden (30\%), kemudian 7-11 bulan berjumlah 5 responden (10\%), 1-3 tahun berjumlah responden $(38 \%)$, dan dengan waktu $>3$ tahun memiliki jumlah terbanyak yaitu sebanyak 7 responden (14\%).

7. Responden Menurut Waktu Pembelian Terakhir

\begin{tabular}{l} 
Jumlah Responden Waktu Pembelian Terakhir \\
\begin{tabular}{|r|c|c|c|}
\hline No. & $\begin{array}{c}\text { Pembelian } \\
\text { Terakhir Kali }\end{array}$ & $\begin{array}{r}\text { Jumlah } \\
\text { (Orang) }\end{array}$ & $\begin{array}{c}\text { Frekuensi } \\
(\%)\end{array}$ \\
\hline 1 & 0-7 Hari lalu & 13 & $26 \%$ \\
\hline 2 & 1-4 Minggu lalu & 6 & $12 \%$ \\
\hline 3 & 1-6 Bulan lalu & 15 & $30 \%$ \\
\hline 4 & 7-12 Bulan lalu & 5 & $10 \%$ \\
\hline 5 & $>1$ Tahun & 11 & $22 \%$ \\
\hline
\end{tabular} \\
\hline
\end{tabular}
diperoleh jumlah responden waktu pembelian tas Rumah Warna terakhir 0-7 hari yang lalu berjumlah 13 responden (26\%), kemudian 1-4 minggu yang lalu berjumlah 6 responden (12\%), 1-6 bulan lalu berjumlah 15 responden (30\%), 7-12 bulan yang lalu berjumlah 5 responden (10\%), dan > 1 tahun berjumlah 11 responden $(22 \%)$. 


\section{Hasil Penelitian}

1. Hasil Uji Validitas

Adapun perhitungan validitas dari keseluruhan variabel yang memenuhi atau dikatakan valid. Memilki nilai factor loading lebih besar dari 0,50 dan membentuk satu component. Data-data tersebut dapat dilihat pada tabel berikut:

\begin{tabular}{|c|c|c|c|c|c|}
\hline Kode & \multicolumn{3}{|c|}{ Faktor Loading } & Status \\
\hline Butir & $\begin{array}{c}\text { Kualitas } \\
\text { Produk }\end{array}$ & $\begin{array}{c}\text { Citra } \\
\text { Merek }\end{array}$ & Harga & $\begin{array}{c}\text { Kepuasan } \\
\text { Konsumen }\end{array}$ & \\
\hline KP 1 & 0,817 & & & & Valid \\
\hline KP 2 & 0,749 & & & & Valid \\
\hline KP 3 & 0,780 & & & & Valid \\
\hline KP 4 & 0,747 & & & & Valid \\
\hline CM 2 & & 0,725 & & & Valid \\
\hline CM 3 & & 0,626 & & & Valid \\
\hline CM 4 & & 0,819 & & & Valid \\
\hline H 1 & & & 0,827 & & Valid \\
\hline H 2 & & & 0,775 & & Valid \\
\hline H3 & & & 0,856 & & Valid \\
\hline H4 & & & 0,735 & & Valid \\
\hline K 1 & & & & 0,745 & Valid \\
\hline K 2 & & & & 0,715 & Valid \\
\hline K 3 & & & & 0,809 & Valid \\
\hline K 4 & & & & 0,877 & Valid \\
\hline
\end{tabular}

Dari tabel di atas dapat kita ketahui bahwa terdapat 15 butir pertanyaan dari jumlah awal 16 butir pertanyaan yang dapat dikatakan valid sesuai standar yaitu memiliki nilai factor loading lebih dari 0,50 dan membentuk satu component.

2. Hasil Uji Reliabilitas

\begin{tabular}{|c|l|c|c|}
\multicolumn{4}{|c|}{ Hasil Uji Reliabilitas pada Seluruh Variabel Penelitian } \\
\hline No & \multicolumn{1}{|c|}{ Variabel } & $\begin{array}{c}\text { Nilai } \\
\text { Cronbhac's } \\
\text { Alpha }\end{array}$ & Hasil \\
\hline 1 & Kualitas Produk (X1) & 0,739 & Reliabel \\
\hline 2 & Citra Merek (X2) & 0,621 & Reliabel \\
\hline 3 & Harga (X3) & 0,807 & Reliabel \\
\hline 4 & Kepuasan Konsumen $(\mathrm{Y})$ & 0,793 & Reliabel \\
\hline
\end{tabular}

Dari tabel di atas, maka hasil dari uji reliabelitas dapat dijelaskan sesuai dengan nilai cronbhac's alpha varibel. Berikut penjelasannya:

a. Kualitas produk pada tas Rumah Warna Yogyakarta, nilai yang dihasilkan oleh variabel ini sebesar 0,739 dimana sesuai ketentuan nilai
0,739 lebih besar dari 0,60 sehingga hasil dari veriabel kualitas produk pada tas Rumah Warna dalam pengujian yaitu reliabel. Dalam variabel ini setiap butir pertanyaan dan jawaban konsisten.

b. Citra merek pada tas Rumah Warna, nilai yang dihasilkan oleh variabel ini sebesar 0,621 dimana sesuai ketentuan nilai 0,621 lebih besar dari 0,60 sehingga hasil dari variabel citra merek pada tas Rumah Warna dalam pengujian yaitu reliabel. Dalam variabel ini setiap butir pertanyaan dan jawaban konsisten.

c. Harga pada tas Rumah Warna, nilai yang dihasilkan oleh variabel ini sebesar 0,807 dimana sesuai ketentuan nilai 0,807 lebih besar dari 0,60 sehingga hasil dari variabel harga pada tas Rumah Warna dalam pengujian yaitu reliabel. Dalam variabel ini setiap butir pertanyaan dan jawaban konsisten.

d. Kepuasan konsumen pada tas Rumah Warna, nilai yang dihasilkan oleh variabel ini sebesar 0,793 dimana sesuai ketentuan nilai 0,793 lebih besar dari 0,60 sehingga hasil dari variabel kepuasan konsumen dalam pengujian yaitu reliabel. Dalam variabel ini setiap butir pertanyaan dan jawaban konsisten.

Berdasarkan analisis yang telah dilakukan dapat disimpulkan bahwa dari seluruh pertanyaan yang ada telah memenuhi ketentuan dengan memiliki nilai cronbhac's alpha lebih dari 0,60 yang menjadikan hasil dari variabel kualitas produk, citra merek dan harga dinyatakan reliabel. Variabel dependen dalam penelitian inipun memiliki nilai cronbhac's alpha 0,793 lebih besar dari 0,60 . Sehingga dari variabel-variabel 
yang dinyatakan reliabel memiliki kekonsistenan antara pernyataan dan jawaban yang diberikan responden.

3. Hasil Uji Regresi Linier Berganda Hasil analisis regresi linier berganda

\begin{tabular}{|c|c|c|}
\hline \multirow{2}{*}{ Model } & $\begin{array}{c}\text { Unststandaridized } \\
\text { Coefisients }\end{array}$ & \multirow{2}{*}{ Sig. } \\
\cline { 2 - 2 } & $\mathrm{B}$ & \\
\hline 1 (Constant) & 0,237 & 0,687 \\
\hline$X_{1}$ & 0,218 & 0,081 \\
\hline$X_{2}$ & 0,337 & 0,032 \\
\hline$X_{3}$ & 0,396 & 0,001 \\
\hline
\end{tabular}

Berdasarkan hasil tersebut dapat diperoleh persamaan regresi sebagai berikut :

$\mathrm{Y}=0,237+0,218 \mathrm{X} 1+0,337 \mathrm{X} 2+$ 0,396X3

Setiap nilai dari persamaan regresi diatas dapat diintepretasikan yaitu:

$\mathrm{a}=0,237$ merupakan nilai constant. Jika nilai dari kualitas produk pada tas rumah warna (X1), citra merek pada tas rumah warna (X2) dan hargapada tas rumah warna (X3) dimisalkan 0 maka nilai dari kepuasan konsumen sama dengan 0,237.

$\mathrm{b} 1=0,218$ koefisien bernilai positif artinya terjadi hubungan positif antara kualitas produk pada tas Rumah Warna (X1) dengan kepuasan konsumen (Y). Jika nilai kualitas produk pada tas Rumah Warna (X1) semakin besar maka nilai kepuasan konsumen (Y) akan besar. Koefisen variabel kualitas produk pada tas Rumah Warna (X1) sebesar 0,218 artinya jika nilai variabel independen lainya tetap dan jika variabel kualitas produk pada tas Rumah Warna (X1) mengalami kenaikan 1 satuan maka kepuasan konsumen (Y) naik sebesar 0,218.

b2 $=0,337$ koefiesien bernilai positif artinya terjadi hubungan positif antara citra merek pada tas Rumah Warna (X3) dan kepuasan konsumen (Y), semakin besar citra merek pada tas Rumah Warna maka akan semakin besar nilai kepuasan konsumen.
Koefisien regresi variabel citra merekpada tas Rumah Warna (X2) sebesar 0,337. Artinya jika variabel independen lain nilainya tetap dan jika variabel citra merek pada tas Rumah Warna (X2) mengalami kenaikan 1 satuan maka kepuasan konsumen (Y) akan naik sebesar 0,337 .

b3 $=0,396$ koefisien bernilai positif artinya terjadi hubungan positif antara harga pada tas Rumah Warna (X3) dan kepuasan konsumen (Y), semakin besar harga pada tas Rumah Warna maka akan semakin besar nilai kepuasan konsumen. Koefisien regresi variabel harga pada tas Rumah Warna (X3) sebesar 0,396. Artinya jika variabel independen lain nilainya tetap dan jika variabel harga pada tas Rumah Warna (X3) mengalami kenaikan 1 satuan maka kepuasan konsumen (Y) akan naik sebesar 0,396.

4. Hasil Uji Parsial (Uji T)

Hasil Uji Signifikansi Parsial (Uji T)

\begin{tabular}{|l|c|}
\hline \multirow{2}{*}{\multicolumn{1}{|c|}{ Variabel }} & Hasil Uji \\
\cline { 2 - 2 } & Sig. \\
\hline Kualitas Produk (X1) & 0,081 \\
\hline Citra Merek (X2) & 0,032 \\
\hline Harga (X3) & 0,001 \\
\hline
\end{tabular}

1. Variabel kualitas produk pada tas Rumah Warna (X1)

Ho: Tidak terdapat pengaruh positif kualitas produk terhadap kepuasan konsumen tas Rumah Warna Yogyakarta.

H1: Terdapat pengaruh positif kualitas produk terhadap kepuasan konsumen tas Rumah Warna Yogyakarta.

Jika dibandingkan antara nilai signifikansi variabel kualitas produk pada tas Rumah Warna sebesar 0,081 dengan alpha 0,05. Maka $0,081>0,05$ sehingga dapat disimpulkan bahwa hipotesis HO diterima dan $\mathrm{H} 1$ ditolak, yang 
artinya kualitas produk pada tas rumah warna tidak berpengaruh terhadap kepuasan konsumen.

2. Variabel citra merek pada tas Rumah Warna (X2)

Ho: Tidak terdapat pengaruh positif citra merek terhadap kepuasan konsumen tas Rumah Warna Yogyakarta.

$\mathrm{H} 2$ : Terdapat pengaruh positif citra merek terhadap kepuasan konsumen tas Rumah Warna Yogyakarta.

Jika dibandingkan antara nilai signifikansi variabel citra merek pada tas Rumah Warna sebesar 0,032 dengan alpha 0,05. Maka $0,032<0,05$ sehingga dapat disimpulkan bahwa hipotesis $\mathrm{HO}$ ditolak dan $\mathrm{H} 2$ diterima, yang artinya citra merek pada tas Rumah Warna berpengaruh positif terhadap kepuasan konsumen.

3. Variabel harga pada tas Rumah Warna (X3)

Ho: Tidak terdapat pengaruh positif harga terhadap kepuasan konsumen tas Rumah Warna Yogyakarta.

H3: Terdapat pengaruh positif harga terhadap kepuasan konsumen tas Rumah Warna Yogyakarta

Jika dibandingkan antara nilai signifikansi variabel harga pada tas Rumah Warna sebesar 0,001 dengan alpha 0,05. Maka $0,001<0,05$ sehingga dapat disimpulkan bahwa hipotesis Ho ditolak dan H3 diterima, yang artinya harga pada tas Rumah Warna berpengaruh positif terhadap kepuasan konsumen.
5. Hasil Uji Simultan (Uji F)

Hasil Analisis Uji F

\begin{tabular}{|c|c|}
\hline Model & Sig. \\
\hline Regresion & 0,000 \\
\hline Residual & \\
\hline Total & \\
\hline
\end{tabular}

Berdasarkan nilai signifikansi yang dihasilkan uji secara simultan dapat dijelaskan sebagai berikut :

Ho: Tidak terdapat pengaruh yang signifikan kualitas produk, citra merek dan harga secara bersamasama terhadap kepuasan konsumen tas Rumah Warna Yogyakarta.

H4: Terdapat pengaruh yang signifikan kualitas produk, citra merek dan harga secara bersamasama terhadap kepuasan konsumen tas Rumah Warna Yogyakarta.

Dari hasil output uji f yang dihasilkan diperoleh nilai dari sig. sebesar 0,000. Jika dibandingkan dengan alpha sebesar 0,05 , maka 0,000 $<0,05$ yang artinya variabel kualitas produk, citra merek dan harga secara bersama-sama berpengaruh signifikan terhadap variabel kepuasan konsumen. Sehingga dapat disimpulkan bahwa $\mathrm{H} 4$ diterima dan Ho ditolak.

\section{Hasil Uji Koefisien Determinasi}

Koefisien determinasi $\mathrm{R}$ square dipergunakan untuk mengetahui presentase variabel dependen yang disebabkan variabel independen. Yang dilihat dari nilai hasil output program SPSS yang mengacu pada kolom Ajusted $\mathrm{R}$ Square dalam pengujian data tersebut diperoleh nilai $\mathrm{R}$ Square sebesar 0,496.

Dari hasil tersebut sehingga dapat diambil kesimpulan bahwa nilai ajusted $\mathrm{R}$ square sebesar 0,496 atau 49,6\% mampu menjelaskan variabel independen kualitas produk, citra merek 
dan harga terhadap variabel dependen kepuasan konsumen, dan sisanya sebesar 50,4\% dipengaruhi oleh variabel lain yang tidak terdapat dalam penelitian.

\section{Pembahasan}

1. Hipotesis 1: Terdapat pengaruh positif kualitas produk terhadap kepuasan pada konsumen tas Rumah Warna Yogyakarta.

Sari (2015) menyatakan bahwa kualitas produk merupakan pemahaman bahwa produk yang ditawarkan oleh penjual mempunyai nilai jual lebih yang tidak dimiliki produk pesaing. Oleh karena itu perusahaan berusaha memfokuskan pada kualitas produk dan membandingkan dengan produk yang ditawarkan oleh perusahaan pesaing. Kualitas produk mencerminkan kemampuan produk untuk menjalankan tugasnya yang mencakup daya tahan, kehandalan, kemajuan, kekuatan, kemudahan dalam pengemasan, reparasi produk dan ciri-ciri lainnya.

Berdasarkan hasil penelitian yang dilakukan oleh Saputri (2017) yang berjudul "Pengaruh Kualitas Produk, Harga, Promosi dan Citra Merek Terhadap Kepuasan Konsumen yang Berdampak pada Loyalitas Konsumen (Studi Pada Konsumen Pengguna Tas Elizabeth di Semarang)" penelitian tersebut merupakan penelitian sebelumnya pada penelitian ini dimana hasil pada penelitian sebelumnya menunjukkan bahwa kualitas produk mempunyai pengaruh yang signifikan terhadap kepuasan konsumen dengan nilai signifikansi sebesar 0,039 (signif $<0,05)$ sehingga mengidentifikasikan bahwa variabel kualitas produk berpengaruh signifikan terhadap kepuasan konsumen.
Berdasarkan usia dalam penelitian sekarang usia responden yang mendominasi adalah usia 18-25 tahun, dimana dalam usia ini responden sudah dapat memutuskan pilihannya dan memasuki tahap usia dewasa, pada usia ini konsumen sudah sangat selektif dalam memilih produk, terlebih lagi mengenai kualitas baik dari segi keawetan, ketahanan bahan baku, model yang mengikuti trend zaman dan terlebih lagi pada modelmodel yang bervariasi, sehingga konsumen pada usia ini sangat gemar dengan tas yang memiliki bahan yang berkualitas, awet dan tahan lama namun tetap mementingkan beragamnya model yang disajikan oleh tas pada suatu merek. Sedangkan dalam penelitian sekarang berdasarkan uji t menyatakan bahwa kualitas produk dalam uji $\mathrm{t}$ mendapatkan nilai signifikansi sebesar 0,081, artinya lebih besar dibandingkan dengan nilai $\alpha=0,05$ sehingga variabel kualitas produk tidak berpengaruh terhadap kepuasan konsumen tas Rumah Warna Yogyakarta.

Selain itu, menurut analisis regresi linier berganda, variabel ini memiliki koefisien regresi yang bernilai positif yaitu sebesar 0.218. hal ini dapat diartikan jika nilai variabel kualitas produk semakin tinggi, maka akan diikuti pula dengan kepuasan konsumen tas Rumah Warna Yogyakarta semakin tinggi pula, dan konsumen akan lebih sering dan tertarik untuk terus membeli tas produksi Rumah Warna.

2. Hipotesis 2: Terdapat pengaruh positif citra merek terhadap kepuasan pada konsumen tas Rumah Warna Yogyakarta.

Lasander (2013) meyatakan bahwa citra merek adalah apa yang 
dipersepsikan oleh konsumen mengenai sebuah merek. Dimana hal ini menyangkut bagaimana seorang konsumen menggambarkan apa yang mereka pikirkan mengenai sebuah merek dan apa yang mereka rasakan mengenai merek tersebut ketika mereka memikirkannya.

Berdasarkan hasil penelitian yang dilakukan oleh Saputri (2017) yang berjudul "Pengaruh Kualitas Produk, Harga, Promosi dan Citra Merek Terhadap Kepuasan Konsumen yang Berdampak pada Loyalitas Konsumen (Studi Pada Konsumen Pengguna Tas Elizabeth di Semarang)" sebagaimana penelitian tersebut dijadikan penelitian sebelumnya pada penelitian ini dimana hasil pada penelitian sebelumnya menunjukkan bahwa citra merek mempunyai pengaruh yang positif dan signifikan terhadap kepuasan konsumen dengan nilai signifikansi sebesar 0,000 (sig $<0,05) \quad$ sehingga mengidentifikasikan bahwa variabel citra merek berpengaruh positif dan signifikan terhadap kepuasan konsumen.

Berdasarkan usia dalam penelitian sekarang usia responden yang mendominasi adalah usia 18-25 tahun, dimana dalam usia ini responden sudah dapat memutuskan pilihannya dan memasuki tahap usia dewasa. Berdasarkan pendidikan terakhir dalam penelitian sekarang yang paling mendominasi yaitu SMA, dimana SMA memiliki tingkat pendidikan yang cukup tinggi dan sebagian besar memiliki ketertarikan akan tas bermerek dalam tingkat pendidikan ini responden biasanya memiliki gengsi yang cukup tinggi terlebih lagi mengenai merek produk yang akan mereka kenakan sehari-hari, salah satunya adalah tas. Berdasarkan jenis pekerjaan dalam penelitian ini yang mendominasi adalah Pelajar / Mahasiswa, dimana pelajar/mahasiswa lebih tertarik dan cenderung mengikuti model yang ada dan cenderung gengsi untuk memilih tas yang mereknya belum terdengar luas sehingga mereka memiliki persepsi berbeda terkait pemikiran mereka seputar tas Rumah Warna.

Penelitian sekarang juga sama dengan penelitian terdahulu, berdasarkan uji $\mathrm{t}$ menyatakan bahwa citra merek dalam uji t mendapatkan nilai signifikansi sebesar 0,032 , artinya lebih kecil dibandingkan dengan nilai $\alpha=0,05$ sehingga variabel citra merek mempunyai pengaruh positif terhadap kepuasan konsumen tas Rumah Warna Yogyakarta. Konsumen tas Rumah Warna mengakui bahwa logo tas Rumah Warna mudah diingat, memberikan kesan modern, simpel dan bagus pada pemakainya, sehingga membuat konsumen puas ketika memakai tas produksi Rumah Warna.

Selain itu menurut analisis regresi linier berganda, variabel ini memiliki koefisien regresi yang bernilai positif yaitu sebesar 0.337. Artinya jika nilai variabel citra merek semakin tinggi, maka akan diikuti pula dengan kepuasan konsumen tas Rumah Warna Yogyakarta untuk merekomendasikan atau membeli kembali tas Rumah Warna karena citra merek tas Rumah Warna mudah diingat, memberikan kesan modern, simpel dan bagus bagi pemakainya.

3. Hipotesis 3: Terdapat pengaruh positif harga terhadap kepuasan konsumen tas Rumah Warna Yogyakarta.

Sutarno (2012) mengatakan bahwa harga adalah isu strategis yang penting karena itu berkaitan dengan positioning 
produk. Selanjutnya, harga mempengaruhi unsur-unsur bauran pemasaran lain seperti fitur produk, keputusan saluran dan promosi.

Berdasarkan hasil penelitian yang dilakukan oleh Saputri (2017) yang berjudul "Pengaruh Kualitas Produk, Harga, Promosi dan Citra Merek Terhadap Kepuasan Konsumen yang Berdampak pada Loyalitas Konsumen (Studi Pada Konsumen Pengguna Tas Elizabeth di Semarang)" sebagaimana penelitian tersebut dijadikan penelitian sebelumnya pada penelitian ini dimana hasil pada penelitian sebelumnya menunjukkan bahwa harga mempunyai pengaruh positif dan signifikan terhadap kepuasan konsumen dengan nilai signifikansi sebesar 0,007 (signif $<0,05)$ sehingga mengidentifikasikan bahwa variabel harga berpengaruh positif dan signifikan terhadap kepuasan konsumen.

Berdasarkan usia dalam penelitian sekarang usia responden yang mendominasi adalah usia 18-25 tahun, dimana dalam usia ini responden sudah dapat memutuskan pilihannya dan memasuki tahap usia dewasa. Berdasarkan pendidikan terakhir dalam penelitian sekarang yang paling mendominasi yaitu SMA, dimana SMA memiliki tingkat pendidikan yang cukup tinggi dan sebagian besar memiliki ketertarikan akan tas bermerek. Berdasarkan jenis pekerjaan dalam penelitian ini yang mendominasi adalah Pelajar/Mahasiswa, dimana pelajar/mahasiswa sudah mulai selektif dan mengerti mengenai harga memungkinkan untuk mempresentasikan kualitas dari sebuah produk, namun tetap terjangkau oleh kantong pelajar/mahasiswa, meskipun dalam hal ini harga yang tinggi menggambarkan kualitas produk yang tinggi pula, sehingga mereka memiliki persepsi berbeda terkait pemikiran mereka seputar tas Rumah Warna.
Penelitian ini juga sama dengan penelitian terdahulu, berdasarkan uji $\mathrm{t}$ menyatakan bahwa harga dalam uji $\mathrm{t}$ mendapatkan nilai signifikansi sebesar 0,001, artinya lebih kecil dibandingkan dengan nilai $\alpha=0,05$ sehingga variabel harga mempunyai pengaruh positif terhadap kepuasan konsumen tas Rumah Warna Yogyakarta. Konsumen tas Rumah Warna mengakui bahwa harga tas rumah warna terjangkau, harga tas rumah warna terjangkau bagi konsumen bahkan jika dibandingkan dengan merek tas lainnya, dan bahkan harga tas Rumah Warna sesuai dengan kualitas tas Rumah Warna.

Selain itu menurut analisis regresi linier berganda, variabel ini memiliki koefisien regresi yang bernilai positif yaitu sebesar 0.396. hal ini dapat diartikan jika nilai variabel harga semakin tinggi, maka akan diikuti pula dengan kepuasan konsumen tas Rumah Warna Yogyakarta yang semakin tinggi pula, karena menurut konsumen dengan meningkatn ya harga yang ditawarkan oleh tas Rumah Warna itu tandanya semakin tinggi pula kualitas produk yang ditawarkan tas produksi Rumah Warna.

4. Hipotesis 4: Terdapat pengaruh kualitas produk, citra merek dan harga secara bersama-sama terhadap kepuasan konsumen tas Rumah Warna Yogyakarta.

Peter (2014) mengatakan bahwa kepuasan konsumen adalah konsep yang paling menentukan dalam pemikiran pemasaran dan riset konsumen. Secara teori, konsumen yang merasa puas dengan produk, jasa atau merek, kemungkinan besar akan terus membelinya dan memberitahukan kepada yang lain perihal pengalamanpengalaman menyenangkan yang dirasakannya dengan produk, jasa atau merek tersebut. Bila tidak puas, kemungkinan besar konsumen akan berganti produk atau merek dan 
mengadukan keluhan kepada produsen barang, pengecer dan konsumen lain.

Berdasarkan penelitian yang dilakukan oleh Saputri (2017) yang berjudul "Pengaruh Kualitas Produk, Harga, Promosi dan Citra Merek Terhadap Kepuasan Konsumen yang Berdampak pada Loyalitas Konsumen (Studi Pada Konsumen Pengguna Tas Elizabeth di Semarang)" sebagaimana penelitian tersebut dijadikan penelitian sebelumnya pada penelitian ini dimana hasil pada penelitian sebelumnya menyatakan bahwa variabel kualitas produk, harga, promosi dan citra merek berpengaruh secara bersamasama terhadap kepuasan konsumen tas Elizabeth di Semarang. Pernyataan tersebut sebanding dengan hasil analisis uji secara simultan yang meperoleh nilai signifikansi sebesar 0,000 (signif $<0,05$ ) yang artinya $\mathrm{Ha}$ diterima dan dari penelitian ini kita ketahui bahwa kualitas produk, citra merek dan harga secara bersama-sama mempengaruhi kepuasan konsumen tas Rumah Warna Yogyakarta, hal ini berarti kepuasan konsumen dipengaruh oleh salah satu variabel bebas dalam penelitian ini.

\section{KESIMPULAN DAN SARAN}

\section{Kesimpulan}

1. Hasil uji t kualitas produk dengan nilai signifikansi 0,081 lebih besar dari pada alfa 0,05 yang artinya kualitas produk pada tas Rumah Warna tidak berpengaruh terhadap kepuasan konsumen tas Rumah Warna Yogyakarta, artinya hipotesis 1 pada penelitian ini ditolak.

2. Hasil uji $\mathrm{t}$ citra merek dengan nilai signifikansi 0,032 lebih kecil dari pada alfa 0,05 yang artinya citra merek pada tas Rumah Warna berpengaruh positif terhadap kepuasan konsumen tas Rumah Warna Yogyakarta, artinya hipotesis 2 pada penelitian ini diterima.
3. Hasil uji $t$ harga dengan nilai signifikansi 0,001 lebih kecil dari pada alfa 0,05 yang artinya harga pada tas Rumah Warna berpengaruh positif terhadap kepuasan konsumen tas Rumah Warna Yogyakarta, artinya hipotesis 3 pada penelitian ini diterima.

4. Hasil uji f kualitas produk, citra merek dan harga dengan nilai signifikansi 0,000 lebih kecil dari pada alfa 0,05 yang artinya kualitas produk, citra merek dan harga pada tas Rumah Warna berpengaruh secara bersamasama terhadap kepuasan konsumen tas Rumah Warna Yogyakarta, menggambarkan bahwa salah satu dari variabel bebas penelitian ini berpengaruh secara signifikan terhadap kepuasan konsumen tas Rumah Warna Yogyakarta, artinya hipotesis 4 pada penelitian ini diterima.

5. Hasil uji determinasi (R2) dengan nilai 0,496 atau $49,6 \%$, dari hasil pengujian ini dapat dijelaskan bahwa variabel kualitas produk, citra merek dan harga mempengaruhi kepuasan konsumen pada tas Rumah Warna sebesar $49,6 \%$ dan untuk sisanya didipengaruhi atau dijelaskan oleh variabel lain.

\section{Saran}

1. Bagi Perusahaan Rumah Warna

a. Hasil dari penelitian ini memang kualitas produk tidak mempengaruhi kepuasan konsumen, tetapi akan jauh lebih baik jika kualitas produk tas rumah warna diperbaiki dan ditingkatkan baik dari segi keawetan produk tas, ketahanan model tas, desain yang menarik dan mengikuti tren zaman yang sedang berkembang serta bahan tas yang tidak mudah rusak. Adanya perbaikan kualitas produk tas Rumah Warna tentu akan meningkatkan rasa puas konsumen sehingga kemungkinan besar bisa sampai pada tingkat loyal. 
b. Hasil penelitian ini bisa disimpulkan bahwa koefisien harga bernilai positif (+) artinya, semakin tinggi harga produk tas Rumah Warna maka akan semakin tinggi pula tingkat kepuasan konsumen tas Rumah Warna Yogyakarta, hal tersebut dikarenakan konsumen tas rumah warna melibatkan gengsi dalam proses memutuskan untuk membeli produk tas yang akan dikenakan sehari-hari. Oleh sebab itu, saran dari penelitian ini tidak masalah apabila toko tas Rumah Warna membandrol harga tasnya dengan harga yang tinggi dan jangan terlalu sering mengadakan promo atau diskon tetapi tetap diimbangi dengan kualitas produk yang baik.

c. Data dari penelitian mengenai tas Rumah Warna ini juga dapat digunakan perusahaan dalam membandingkan harapan dan persepsi pelanggan, atau hasil yang didapat dari kepuasan konsumen tas Rumah Warna Yogyakarta dengan kepuasan konsumen tas perusahan lainnya. Sehingga harapan kedepannya Rumah Warna dapat memperbaiki komponen-komponen yang masih dirasa kurang mampu memuaskan konsumen tas Rumah Warna Yogyakarta.

\section{Saran Bagi Peneliti Berikutnya}

a. Peneliti menyarankan bagi peneliti selanjutnya sebaiknya menggunakan sampel lebih banyak dari pada penelitian ini, mengingat jumlah sampel sekarang ini berjumlah 50 responden dengan perbandingan banyaknya toko tas Rumah Warna yang tersebar di Yogyakarta.

b. Bagi peneliti selanjutnya sebaiknya tidak hanya melakukan penelitian pada satu toko tas Rumah Warna yang ada di Yogyakarta karena toko tas Rumah Warna tersebar cukup banyak di kota Yogyakarta.

c. Peneliti menyarankan kepada peneliti selajutnya untuk meneliti ukuran indikator komponen kunci kepuasan konsumen secara lebih spesifik terhadap kontribusi hubungan pelanggan oleh sebuah perusahaan agar indikator-indikator dari kepuasan konsumen pada tas Rumah Warna dapat terukur dengan tepat. Mengingat nilai Adjusted $\mathrm{R}$ Square yang masih kecil.

\section{DAFTAR PUSTAKA}

Adhilla, Fitriani dan Ismanto. (2014). Petunjuk Praktikum STATISTIK 2. Yogyakarta: Laboratorium Fakultas Ekonomi Program Studi Manajemen. Firrahim, Rauf. (2018). Kualitas Pelayanan Pendidikan Tinggi Fakultas Ekonomi dan Bisnis Universitas Ahmad Dahlan. Skripsi Tidak Dipublikasikan.

Kunaifi, Dede Aang. (2015). Pengaruh Kualitas Produk dan Citra Merek Tehadap Kepuasan Konsumen pada Produk Eiger di Surakarta. Naskah Publikasi. Surakarta: Universitas Muhammadiyah Surakarta.

Lasander, Christian. (2013). Citra Merek,

Kualitas Produk dan Promosi

Pengaruhnya Terhadap Kepuasan

Konsumen Pada Makanan

Tradisional. Jurnal EMBA (September). hal. 284-293.

Peter, J Paul dan Jerry C. Olson. (2014). Perilaku Konsumen dan Strategi Pemasaran. Jakarta: Salemba Empat.

Rahmasari, Desiana. (2015). Pengaruh Citra Merek, Harga dan Kualitas 
Produk Terhadap Kepuasan

Konsumen Tas Merek Guess di

Surabaya. Optimum (Oktober), hal. $1-12$.

Rochman, Abdul. (2017). Pengaruh Kualitas Pelayanan, Kualitas Produk, Harga dan Citra Merek Terhadap Kepuasan Konsumen. Optimum (Autumn) hal. 1-17.

Sari, Fanny P., dan Tri Yuniati. (2016). Pengaruh Harga, Citra Merek, dan Word Of Mouth terhadap Keputusan Pembelian Konsumen. Jurnal Ilmu dan Riset Manajemen (Juni), hal. 115.

Sari, Rika Mwarni. (2015). Pengaruh Kualitas Produk dan Kepuasan Konsumen Terhadap Loyalitas Pelanggan Sophie Martin di Surakarta. Naskah Publikasi. Surakarta: Universitas Muhammadiyah Surakarta.

Saputri, Eviana Herlin. (2017). Pengaruh Kualitas Produk, Harga, Promosi dan Citra Merek Terhadap Kepuasan Konsumen yang Berdampak pada Loyalitas Konsumen. Optimum (Autumn) hal. $1-18$.

Sugiyono. (2017). Metode Penelitian Kuantitatif, Kualitatif, dan $R \& D$. Bandung: Alfabeta.

Supangkat, Aditya Hangga, dan Supriyatin. (2017). Pengaruh Citra Merek, Kualitas Produk dan Harga Terhadap Keputusan Pembelian Tas di Intako. Jurnal Ilmu dan Riset Manajemen (September), hal. 1-19.

Sutarno. (2012). Serba-serbi Manajemen Bisnis. Yogyakarta: Graha Ilmu.

Tjiptono, Fandy, dan Chandra, Gregorius. (2012). Pemasaran Strategik: Mengupas Pemasaran Strategik, Branding Strategy, Customer Satisfaction, Strategy Kompetitif, hingga e-Marketing. Yogyakarta: Andi Offset. 